\title{
Consumers' preferences and willingness to pay for personalised nutrition
}

Original paper: Pérez-Troncoso, D., Epstein, D.M. \& Castañeda-García, J.A. Consumers' Preferences and Willingness to Pay for Personalised Nutrition. Appl Health Econ Health Policy (2021). https://doi.org/10.1007/s40258-021-00647-3

Daniel Pérez-Troncosoํㅜ, David M. Epstein ${ }^{1}$, José A. Castañeda-García²

Abstract | Introduction: Personalised nutrition (PN) has great potential for disease prevention, particularly if coupled with the power and accessibility of mobile technology. However, success of PN interventions will depend on the willingness of users to subscribe. This study investigates the factors associated with potential users' perceived value of PN and heterogeneity in these values. Methods: A discrete choice experiment was carried out in a representative sample ( $N=429$ valid responses) from the adult population in Spain. The results were analysed in line with McFadden's Random Utility Theory, using conditional and mixed logit models in addition to a latent class logit model. Results: The conditional and mixed logit models revealed the existence of a significant preference and willingness to pay for personalized nutrition, but the effect on average was not large for the highest level of personalization. The latent class logit revealed four classes of respondent: those who would be likely to pay for a high level of personalized nutrition service, those who would use it if it were heavily subsidized, those who would use only a basic nutrition service, and those who would not be willing to engage. These results could be useful for the design and targeting of effective personalized nutrition services. Conclusions: Over half of adults currently perceive some individual benefit in a high level of PN, which may justify some degree of public subsidy in investment and delivery of such a service.

\section{Key points for decision-makers}

- We found four classes of consumers depending on their attitude through personalised nutrition and their individual characteristics.

- Half of adults currently perceive some individual benefit in high levels of personalised nutrition.

- Digital service delivery is feasible from consumers' point of view, leading to a reduction in provision costs.

Keywords: personalised nutrition; willingness to pay; noncommunicable diseases prevention; discrete choice experiment.

\section{Introduction}

Over $60 \%$ of annual deaths worldwide are caused by non-communicable diseases (NCDs) (1) and between $60 \%-70 \%$ of primary care visits in developed countries are associated with conditions linked to lifestyle (2). These modifiable risk factors, such as unhealthy nutrition, sedentary lifestyle, smoking, and alcohol abuse, are related to the five major NCDs (3). These diseases cause suffering and cost society worldwide $\$ 17.3$ trillion a year in terms of health care, lost productivity and lost capital (4). While an individual's genetics plays an essential role in the incidence of NCDs (5), their prevention can benefit public health.

Nutrition has a substantial role in disease prevention (6), and a recent body of knowledge is pointing to new notions. For instance, $\mathrm{Hu}$ (7) suggested that analysing each nutrient's effect

\footnotetext{
${ }^{1}$ Dpt. Applied Economics, University of Granada

2 Dpt. Marketing and Market Research, University of Granada
} 
independently from the others might be an incomplete approach. The single-nutrient model omits the consequences of nutrients acting together and food synergy in the gut microbiome. While studies have shown some single nutrients can modify surrogate outcomes, these have not proved to be effective against major NCDs (8). Interventions based on improving overall healthy diet appear more promising (8), but there continues to be controversy over the extent to which individual-level personalisation is effective [10-12].

Personalised nutrition (PN), nutritional advice based on individual's information (12), is a broad term that covers many different types of intervention. One research line suggests there might be significant potential for personalised nutrition based on very precise individual characteristics (1416). The motivation for the current study arises from the Stance4HEALTH project (16) which aims to develop a new mobile phone app to deliver a personalised dietary intervention. Users value the convenience of online dietary interventions (17) and digital platforms may be effective and cost-effective compared with traditional approaches (18-19) though further evidence is needed. The widespread ownership of mobile phones now might be an opportunity to broadly deliver such interventions, including in low- and middle-income countries (17), and the digital trend is likely to accelerate in the post-COVID world. However, the individual's willingness and ability to make the behaviour change recommended by the app depends on multiple factors, such as income and social class, leading to concerns about widening digital health inequality (18). Hence gaining insights into the factors that influence adoption and adherence to personalised behaviour interventions is an important priority for app developers and intervention designers (19).

The current study uses a discrete choice experiment (DCE). A DCE is a survey instrument where respondents choose between different conceptual products/services in order to elicit consumers' Willingness to Pay (WTP) and personalised nutrition preferences. WTP is the hypothetical amount that the consumers would be willing to pay for the expected outcome of the dietary intervention (or its features), such as health gain (20). WTP is an appropriate measure of consumer preference in this setting because (unlike health-care services), the general population is familiar with the concept of paying for nutrition services and hence are likely to engage with the study. The DCE instrument enables WTP to be estimated using a coherent, rigorous and flexible methodological framework, which, if carefully applied, can overcome some of the biases and imprecisions associated with other methods, such as contingent valuation (21). DCEs provide further information. The "part-worths" are coefficients which show the relative importance of each attribute level. This feature of DCE can offer information about which attributes will increase the probability that the average user will adopt a hypothetical PN, independently from the perceived monetary value. Finally, the DCE can investigate variation in the population (preference heterogeneity) (22), giving important insights into how group differences in social class, education, and other characteristics influence consumer preferences. From the point of view of a commercial intervention designer, such information points to the market segments most likely to purchase a personalised nutrition intervention, should it become available on the market (23). However, more significantly from a public health perspective, national health services or social 
insurers can gain an understanding of identifiable segments of the population who do (or do not) perceive a degree of benefit in personalised nutrition, and hence would be likely (or unlikely) to subscribe even if they personally could not or would not pay for it. Such information can help policymakers estimate the likely uptake of the app among the general public and population subgroups, possibly at different levels of public subsidy, and hence anticipate the impact of a future intervention built around an app on public health and health inequalities.

Information on perceptions of users is crucial at all stages in the product development cycle (24). A DCE is useful at this early stage because it allows users to state their preferences over several hypothetical scenarios, allowing the study investigators to estimate consumer interest in a high degree of personalised nutrition. Any proposed intervention would need be evaluated more formally in a randomised controlled trial. Therefore, this research aims to: 1) quantify consumers' preferences for personalised nutrition, 2) investigate the relationship between preferences and sociodemographic characteristics, 3) inform the debate on public or private provision of personalised nutrition services.

\section{Methods}

\subsection{Literature review of previous studies}

A literature review was carried out to identify the important themes related to demand, willingness to pay and use of personalised nutrition or digital nutrition platforms as a means of health improvement or disease prevention (methods and results in Supplementary Material (SM) A). 18 papers were found covering a range of methodologies: 6 DCEs, 9 consumer surveys, 1 quasiexperimental study, 1 focus group, and 1 Markov model.

Users highlight the convenience of telehealth interventions (25) and such platforms may be effective in improving overall health and cost-effective (18-19). Users' prior perception of the benefits influential in their willingness to engage (26-28). Health improvement and disease prevention stand out as motives to follow a personalised nutrition intervention (29), especially among people with existing NCD (such as diabetes) (30). The degree of personalisation (31), attention to coaching and monitoring (32), and the involvement of professional nutritionists (29) are drivers of effectiveness. Furthermore, there is a level of community reinforcement due to the general belief that people have responsibility to look after their health (33). People might be categorised as supporters, neutrals and unsupportive $(34,35)$ in their attitude to PN. Neutrality or non-support might be caused by data privacy concerns $(26,27,29,32,33,36)$ and expected out-ofpocket costs $(30,37)$. Paying for a personalised nutrition intervention symbolised commitment to behaviour change $(32,38)$. In Europe, one third of the population is willing to pay for personalised nutrition (price found to be around €30-40) (27). Our research aims to build on the existing literature by examining the intensity of consumer preferences and WTP depending on the personalised nutrition programme's characteristics.

2.2. Review of attributes of nutrition apps available in the digital marketplace 
To define attributes and levels for our study, we carefully looked at 9 apps (15 different versions and up to 20 different functionalities) and created an extensive list of possible attributes and levels (39) (SM B). We added to the list the attributes identified in the literature review, particularly Fischer's (27) paper about nutrition care. Finally, we discarded or reformulated those functionalities where we found overlapping, reiteration or interdependence, retaining those features more commonly used in the set of apps reviewed. Thus, we created an early selection of attributes and levels (SM B).

\subsection{Pretests and refinement}

With the early attributes and levels selection, we designed a pilot $4^{2} \times 2^{3}$ optimal design (40) with 16 choice sets per respondent and 2 alternatives per choice. Two experts in health economics, surveying and experimentation evaluated the pilot survey. The survey was conducted online on an $\mathrm{N}=40$ convenience sample. We collected feedback from respondents and colleagues, and we modified the attributes and levels selection (details in SM B). Using the attributes and levels selection in Table 10 (SM B), we created a new $4^{2} \times 2^{4}$ design and conducted another online survey on an $\mathrm{N}=52$ sample of the Spanish population (population-representative respondent panel). However, a large proportion of respondents showed lack of engagement with the DCE task (details in SM B). To solve this, we introduced several changes: 1) we simplified the text in the choice sets and reduced the number of attributes from 6 to 4 (in line with the suggestions of a nutritionist, attributes "personalisation" and "follow-up" were combined and attribute "supplements" was deleted due to controversy surrounding the use of nutritional supplements (41)), 2) we improved the mobile site because many responses were sent from smartphones, and gamified the choice sets using icons that matched the functionality represented by the level of the attribute, 3) we included a one-minute timer in the introduction to oblige the respondents to read the instructions of the survey, 4) we introduced a warm-up question (SM B, Fig. 3).

\subsection{Selection of attributes and levels for the final experiment}

As a result of the pretest process, we ended up with a third and definitive $4^{2} \times 2^{2}$ experimental design with the attributes and levels displayed in Table 1. The first attribute was degree of personalisation, with 4 levels. The second was delivery format with two levels, one for on-site service (i.e. face-to-face) and another for digital delivery of the service (via mobile app and webpage). The third attribute was physical activity training plan (included or not), and the fourth attribute, price, was set up to four levels: $10 €, 20 €, 30 €$ and $40 €$ (monthly) to correspond with the 4 levels of personalisation. Prices of $10-30 €$ are broadly in line with those in the existing digital PN market (SM B) and the literature(27). We included an upper price level of $40 €$ because the microbiome analyses at our highest level of personalisation carry considerable additional expense. We did not include a $0 €$ or very low price level because such a service would need to be financed by advertisements or similar, which would complicate data privacy issues.

\subsection{Discrete Choice Experiment design}

Once we decided on the final attributes and levels specification, we designed the choice sets that would be presented to respondents. We reduced the design to a two-alternative D-efficient DCE 
using the -dcreate- module for Stata (Release 14; StataCorp., 2015) (42). The algorithm reduces the design's D-error (a measure of the estimators' variance) based on prior coefficients and meets the requirements of efficient choice design, i.e. orthogonality, level balance, minimal overlap, and utility balance (further details in SM C). Thus, we obtained a D-efficient design [29, 30] with 16 choice sets separated into two blocks (relative D-efficiency: $84.32 \%$ ).

Table 1. Attributes and levels final selection

\begin{tabular}{|c|c|c|}
\hline \multirow{5}{*}{$\begin{array}{l}\text { Attributes } \\
\text { Personalisation } \\
\text { level }\end{array}$} & \multicolumn{2}{|l|}{ Levels } \\
\hline & Level 1 & Healthy suggestions and nutritional education. \\
\hline & Level 2 & $\begin{array}{l}\text { Diet automatically personalised (by an algorithm) based } \\
\text { on age, weight and height. }\end{array}$ \\
\hline & Level 3 & $\begin{array}{l}\text { Personalised diet set up by a licensed nutritionist based } \\
\text { on age, weight, height, sports habits and blood test. }\end{array}$ \\
\hline & Level 4 & $\begin{array}{l}\text { Personalised diet set up by a licensed nutritionist based on } \\
\text { all the information mentioned before plus gut microbiome } \\
\text { analysis. }\end{array}$ \\
\hline \multirow[t]{2}{*}{ Delivery format } & On-site & $\begin{array}{l}\text { All services are provided in a physical facility that the user } \\
\text { needs visit (with a frequency that depends on their } \\
\text { personalisation level) }\end{array}$ \\
\hline & Digital & $\begin{array}{l}\text { All services (except blood and microbiome analyses) are } \\
\text { provided through a digital platform via smartphone or } \\
\text { computer. }\end{array}$ \\
\hline \multirow[t]{2}{*}{ Training plan } & No & No physical activity training plan. \\
\hline & Included & $\begin{array}{l}\text { Physical activity training plan (the user gets a daily exercise } \\
\text { schedule adapted to their needs). }\end{array}$ \\
\hline \multirow[t]{4}{*}{ Price } & $10 €$ & $10 € /$ month \\
\hline & $20 €$ & $20 € /$ month \\
\hline & $30 €$ & $30 € /$ month \\
\hline & $40 €$ & $40 € /$ month \\
\hline
\end{tabular}


Figure 1. Example choice set

\subsection{Survey design}

The survey was built in Qualtrics (Release 03/2020; Qualtrics, 2020) and comprised three parts. $1^{\text {st }}$ ) An introductory text (which we discussed with a licensed nutritionist) (SM B), a training question, a scale (from 0 to 10) asking respondent's interest in healthy nutrition, and a timer for the respondents to read the introduction. $2^{\text {nd }}$ ) The DCE itself plus a verification question with a dominant alternative (more functionalities at lower prices) to test the responses' rationality. Each block was randomly assigned to $50 \%$ of respondents, and choice sets were randomly displayed within each block. We forced respondents to choose between A or B and did not include an optout option (Figure 1). Given our pilot test experience, we considered that a substantial number of respondents might opt for quick termination of the survey by always choosing the null option and giving lexicographic preferences. Other DCEs have followed this approach (45). Finally, to conduct a sensitivity analysis that tor account that some participants would natsubscribe to any option, we included a final question asking for the probability that the respondent would purchase the options they have chosen if they were available in the market. $\left.3^{\text {rd }}\right) 11$ questions about the sociodemographic status of the respondents (Table 2).

\subsection{Online delivery of survey}

We selected the best option among 5 different agencies according to pricing, services included, and professional experience in research surveys. The agency manages a large consumer panel that is representative of the general adult population in Spain from 18 to 78 years old. Participants receive a small fee (around $€ 0.50$ ) for completing an online questionnaire. The agency's sampling

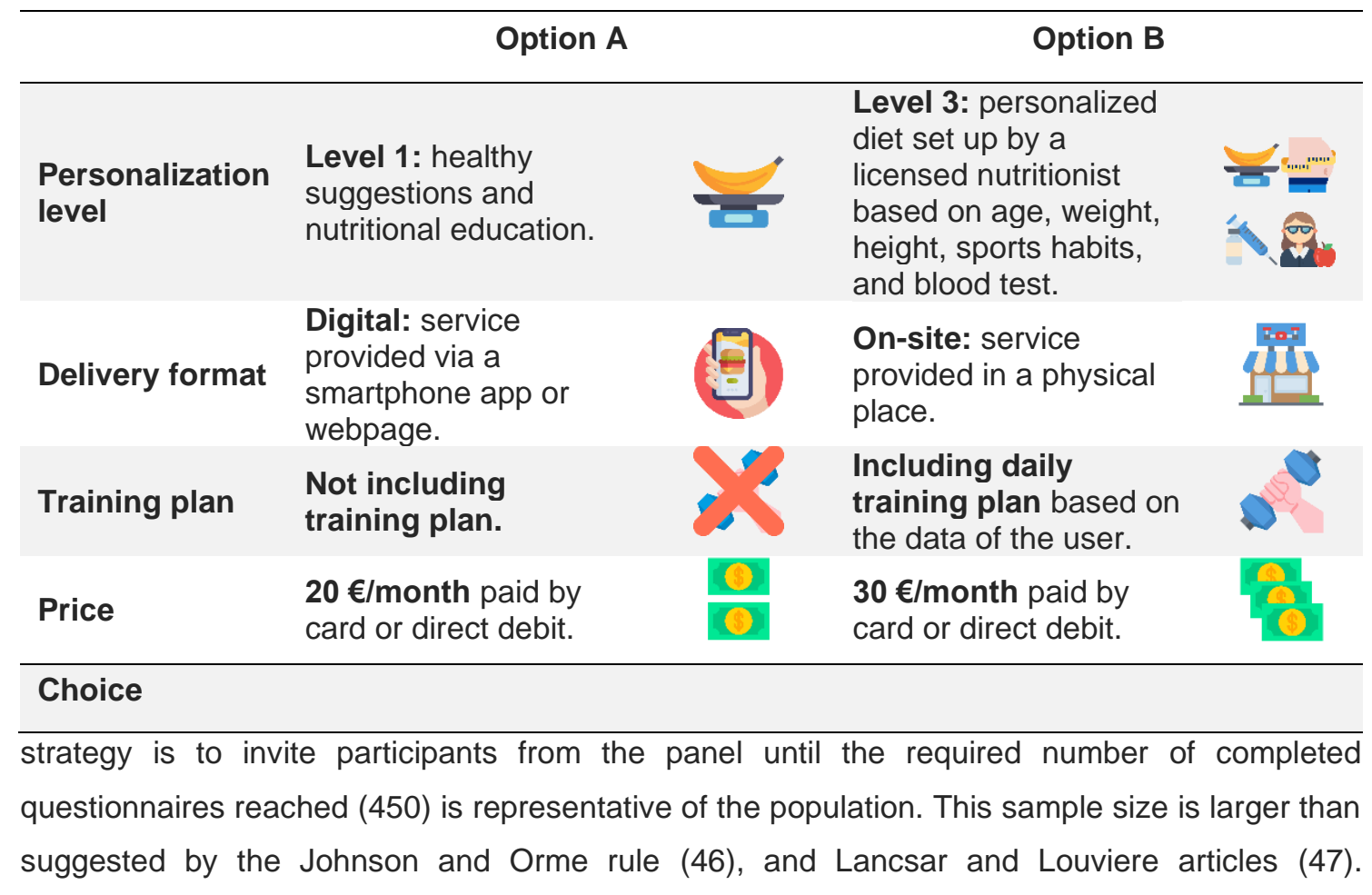


Respondents received an email with the link to the survey and completed it in the Qualtrics interface that we programmed. All surveys were completed in March 2020.

\subsection{Analysis of results}

Three analysis models were fitted to the data (1) Conditional logit (CLM) (2) Mixed logit (XLM) (3) Latent class logit (LCL). In Stata, the results were codified in long shaped format with a row per alternative, so there were $8 \times 2=16$ rows with the same respondent id. The variables of the model were classified by columns. The binary dependent variable was 1 for the selected alternative and 0 otherwise. The attributes were also sorted by columns in dummy coding. Thus, each attribute's level is a variable that takes the value 1 when the alternative contains it or 0 otherwise, except for the price attribute which we codified as a single continuous variable (SM C). We started fitting a conditional logit model (SM C). The CLM can be interpreted using McFadden random utility theory (48) to assign an amount of utility to each alternative based on its characteristics (levels).

$$
u_{j}=X_{j} \beta+\varepsilon_{j}
$$

This relationship is denoted in Equation (1) where the utility of the $j$-ith alternative is given by a vector of the alternative's characteristics (levels), $X_{j}$, and its coefficients, $\beta$, plus other unobserved sources of utility, $\varepsilon_{j}$. The $\beta$ for a given attribute level, sometimes termed part-worth, can be interpreted as the importance (utility) that participants give to that alternative, ceteris paribus, compared with the reference level. We can also interpret $\beta$ as the $\log$ of the odds ratio that participants would choose a product with that attribute level, ceteris paribus, compared with a product with the reference attribute level. Thus, the logit probabilities formula to the probability of choosing alternative $i$ among $J$ different alternatives (Equation 2) [33, 34].

$$
\operatorname{Pr}(\text { choice }=i)=\frac{e^{X_{i} \beta}}{\sum_{j=1}^{J} e^{X_{j} \beta}}
$$

CLM assumes fixed effects (it only estimates average coefficients), so we fitted another model to capture taste heterogeneity. The XLM (random parameters logit model or mixed logit model) performs a simulation of $\beta$ s over a normal distribution (more details in SM C) for each individual, so the mixed logit probability formula is a weighted average of the Equation 2 (51). In this case, we specify the utility by adding the sub-index $n$ (for individuals) in the betas (Equation 3 ). The added flexibility should ensure better model fit for the XLM than the CLM.

$$
u_{n j}=X_{j} \beta_{n}+\varepsilon_{j}
$$

We also fitted a Latent Class Logit (LCL) model, an extension of the conditional logit model. In this model, we have $C$ classes of respondents, where a CLM is estimated for each class $c$. Thus, the probability that a respondent $n$ belong to $c$ is given by (52)

$$
\operatorname{Pr}(n \text { belongs to } c)=\frac{e^{z_{n} \theta_{c}}}{1+\sum_{l=1}^{C-1} e^{z_{n} \theta_{l}}} .
$$


To decide $C$, we computed 4 different $L C L$ models with $C=2,3,4,5$, and used Information Criteria measures to select the best fitting model. After several iterations, we included the sociodemographic characteristics that were significant at the 0.10 level for one or more of the classes.

Finally, willingness to pay was estimated for the XLM and the LCL as the ratio of the attribute's level coefficient and the price coefficient (and Cl limits using the -nlcom- [non-linear combination] command in Stata). For this calculation, we needed the price variable to be continuous, which makes the interpretation of its coefficient to be the change in the log-odds of choosing the product following a one-euro increase in price, ceteris paribus.

\section{Results}

462 respondents completed the survey, but 33 did not answer the verification question correctly and were excluded from the models' estimation. 2100 invitations were sent to achieve this sample. The sociodemographic characteristics of the included respondents are shown in Table 2. Women accounted for $53 \%$ of the sample, the mean age was 42.8 years old and the mean body mass index of respondents was $25.9 \mathrm{~kg} / \mathrm{m}^{2}$. On average, the respondents belonged to households with 4 members and showed a high interest in healthy nutrition (mean 7.99/10, SD 1.92). Comparing the sample demographics with official statistics (https://www.ine.es/), the mean age and income were representative whereas overweight women and obese men were slightly overrepresented in our sample, and household size was larger than the population mean. Besides, our sample includes people with a higher educational level than the national average (SM D).

\subsection{The conditional and mixed logit model}

In the CLM and the XLM, all coefficients were significant except for the delivery format attribute. The coefficients can be interpreted as the weight of the individuals' preferences, and comparisons can be made with respect to the base level of the same attribute and other attributes' levels. Table 3 shows that both models yielded qualitatively similar solutions. The respondents stated strong and significant preferences for higher levels of personalisation and the inclusion of a physical activity training plan.

Table 2. Sociodemographic characteristics of the sample

\begin{tabular}{lcc}
\hline Variable & $\%$ & $\mathbf{n}$ \\
\hline $\mathbf{N}$ & 100 & 462 \\
Age a & 42.80 & 12.80 \\
Height $^{\text {a }}$ & 168.95 & 9.19 \\
Weight $^{\text {a }}$ & 74.03 & 15.44 \\
Sex & & \\
$\quad$ Female & 53.03 & 245 \\
$\quad$ Male & 46.97 & 217 \\
Education & & \\
$\quad$ No education & & \\
$\quad$ Primary education & 0 & 0 \\
& 0.65 & 3
\end{tabular}




\begin{tabular}{lcc} 
Secondary education & 8.44 & 39 \\
Pre university education & 18.18 & 84 \\
Vocational formation I & 12.99 & 60 \\
Vocational formation II & 12.77 & 59 \\
University degree & 35.50 & 164 \\
Postgraduate & 11.47 & 53 \\
Household income (monthly) & & \\
No income & 3.46 & 16 \\
less than 500€ & 4.76 & 22 \\
500€ - 1,000€ & 10.61 & 49 \\
1,000€ - 1,700€ & 28.14 & 130 \\
1,700€ - 2,300€ & 19.05 & 88 \\
2,300€ - 3,000€ & 16.45 & 76 \\
3,000€ - 4,000€ & 11.04 & 51 \\
4,000€ - 5,000€ & 5.19 & 24 \\
more than 5,000€ & 1.30 & 6 \\
No. Of household members ${ }^{\text {a }}$ & 3.06 & 1.18 \\
No. of members under 18 years old & 0.76 & 0.88 \\
No. of employed members & 1.50 & 0.81 \\
No. of unemployed members & 0.73 & 0.88 \\
No. of weekly hours of sport a & 3.75 & 2.89 \\
Level of interest in healthy nutrition a & 7.98 & 1,92 \\
No. of people with any NCD & 21.65 & 100 \\
\hline
\end{tabular}

${ }^{a}$ The columns are mean and SD instead of $\%$ and $n$.

The XLM performed substantially better ( $\rho^{2}$ is among McFadden's recommended values (0.2-0.4) (53) and information criteria are lower for the Akaike (AIC) and Bayesian (BIC) information criterion). Thus, we decided to estimate the WTP based on the XLM estimation. WTP is higher when the personalisation level includes advice from a licensed nutritionist $(+16.16 €$ monthly for level 3 personalisation (Table 3 ), compared with level 2 ) but only an average additional $+1.38 €$ for the highest level of personalisation (gut microbiota analysis) compared with level 3 . The delivery format is only significant at $10 \%$ with a mean WTP of $1.43 €$ for the digital format compared with the non-digital format. The exercise functionality is relatively important with a mean WTP of $13.59 €$.

Table 3. Results from the conditional and mixed logit model + WTP estimation

\begin{tabular}{|c|c|c|c|c|c|c|}
\hline & & \multicolumn{2}{|c|}{ CLM } & \multicolumn{3}{|c|}{ XLM } \\
\hline Attr. & Levels & Coef. & $S E(P>z)$ & Coef. & $S E(P>z)$ & $S D(P>Z)$ \\
\hline & Level 2 & 0.310 & $\begin{array}{c}0.088 \\
(>0.000)\end{array}$ & 0.491 & $\begin{array}{c}0.152 \\
(0.001)\end{array}$ & $\begin{array}{c}1.2133 \\
(>0.000)\end{array}$ \\
\hline Person. & Level 3 & 1.202 & $\begin{array}{c}0.080 \\
(>0.000)\end{array}$ & 2.295 & $\begin{array}{c}0.164 \\
(>0.000)\end{array}$ & $\begin{array}{c}0.4375 \\
(0.07)\end{array}$ \\
\hline & Level 4 & 1.307 & $\begin{array}{c}0.094 \\
(>0.000)\end{array}$ & 2.450 & $\begin{array}{c}0.176 \\
(>0.000)\end{array}$ & $\begin{array}{c}1.1288 \\
(>0.000)\end{array}$ \\
\hline Delivery & Digital & 0.046 & $\begin{array}{c}0.051 \\
(0.160)\end{array}$ & 0.160 & $\begin{array}{c}0.091 \\
(0.079)\end{array}$ & $\begin{array}{c}1.4117 \\
(>0.000)\end{array}$ \\
\hline
\end{tabular}




\begin{tabular}{|c|c|c|c|c|c|c|}
\hline Exercise & Included & 0.831 & $\begin{array}{c}0.060 \\
(>0.000)\end{array}$ & 1.517 & $\begin{array}{c}0.116 \\
(>0.000)\end{array}$ & $\begin{array}{c}1.5210 \\
(>0.000)\end{array}$ \\
\hline Price & (lineal) & -0.056 & $\begin{array}{c}0.005 \\
(>0.000)\end{array}$ & -0.112 & $\begin{array}{c}0.010 \\
(>0.000)\end{array}$ & $\begin{array}{c}0.1161 \\
(>0.000)\end{array}$ \\
\hline
\end{tabular}

Pseudo $R^{2}\left(\rho^{2}\right): 0.1794$

Pseudo $R^{2}\left(\rho^{2}\right): 0.2579$

L-pseudolikelihood: -

1952.0002

L-pseudolikelihood: -1733.6422

AIC: $3916 \quad$ AIC: 3491.284

BIC: 3957.005

\begin{tabular}{lllll}
\hline WTP & Levels & WTP (mean) & WTP (lower limit) & WTP (upper limit) \\
(XLM) & Level 2 & $4.4 €^{* * *}$ & $1.87 €$ & $6.92 €$ \\
& Level 3 & $20.56 €^{* * *}$ & $17.34 €$ & $23.77 €$ \\
& Level 4 & $21.94 €^{* * *}$ & $18.87 €$ & $25.02 €$ \\
& Digital & $1.43 €^{*}$ & $-0.18 €$ & $3.04 €$ \\
& $\begin{array}{l}\text { delivery } \\
\text { Exercise }\end{array}$ & $11.11 €$ & $16.06 €$ \\
included & $13.59 €^{* * *}$ & 11 &
\end{tabular}

Attr.: Attributes, WTP: Willingness to pay (compared with the reference level for that attribute), CLM: conditional logit model, XLM: mixed logit model, AIC: Akaike information criterion, BIC: Bayesian information criterion, $P>z$ : $p$-value, $S D$ : Between-subject standard deviations (random coefficient) (if $p$-value $<0.05$, there is preference heterogeneity). Note: the first level of each attribute is constricted to zero and omitted. All variables are dummy coded except for the price variable, which was specified as a continuous variable. *: $p$-value $<0.10$, **: $p$-value $<0.05$, ***: $p$-value $<0.01$ (only in 'mean' but same for all row).

\subsection{Latent class mixed logit}

The $m=4$ classes LCL model (Table 4) showed the best fit on corrected AIC and BIC (compared with $C=2,3,4,5$.$) . We also iterated the model's estimation, including and excluding$ sociodemographic variables until we found those that were significant for at least one class at the $5 \%$ level. Regardless of the sociodemographic variables, the AIC and BIC information criteria always were lower in the 4 classes model.

Class 1 has relatively weak but significant preferences for levels 3 and 4 of personalisation, but there were no significant differences between those levels $(p=0.9551)$. This is the class where the digital format is more valued. They have relatively low preference for the physical activity training plan. This finding might be associated with the higher levels of education and sedentarism in this group than the sample average. They stated they were willing to acquire the selected alternatives with a probability of $45 \%$.

Table 4. Results from the latent class logit + WTP estimation

\begin{tabular}{|c|c|c|c|c|c|c|}
\hline & Attr. & $\begin{array}{l}\text { Levels } \\
\% \text { of } \\
\text { population }\end{array}$ & $\begin{array}{l}\text { Class 1 } \\
16.67 \%\end{array}$ & $\begin{array}{l}\text { Class } 2 \\
32.68 \%\end{array}$ & $\begin{array}{l}\text { Class } 3 \\
21.65 \%\end{array}$ & $\begin{array}{c}\text { Class } 4 \\
29 \%\end{array}$ \\
\hline \multirow{6}{*}{ 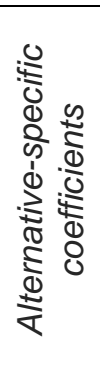 } & Person. & Level 2 & 0.651 & $1.027^{* \star *}$ & 0.640 & $0.469^{* *}$ \\
\hline & & Level 3 & $1.597^{\star * *}$ & $2.153^{* \star *}$ & $3.405^{\star * *}$ & $0.489^{* *}$ \\
\hline & & Level 4 & $1.583^{\star * \star}$ & $2.272^{\star \star \star}$ & $3.785^{\star * *}$ & 0.159 \\
\hline & Delivery & Digital & $1.647^{\star \star *}$ & $-0.284^{\star \star}$ & -0.253 & $-0.763^{* \star *}$ \\
\hline & Exercise & Included & $0.524^{* * *}$ & $2.514^{* * *}$ & $0.602^{* * *}$ & -0.157 \\
\hline & Price & (lineal) & $-0.068^{* * *}$ & $-0.083^{* * *}$ & $-0.027^{* *}$ & $-0.169^{* * *}$ \\
\hline \multicolumn{3}{|c|}{ Characteristics } & Class 1 & Class 2 & Class 3 & Class 4 \\
\hline
\end{tabular}




\begin{tabular}{|c|c|c|c|c|c|c|}
\hline \multirow{8}{*}{ 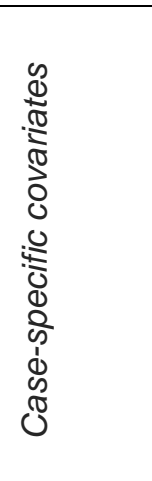 } & \multicolumn{2}{|c|}{ Income (range 1-7) } & 0.190 & 0.128 & $0.351^{* * *}$ & (Reference \\
\hline & \multicolumn{2}{|c|}{ Education (years) } & $0.207^{\star *}$ & -0.096 & -0.100 & class) \\
\hline & & Age & -0.017 & -0.019 & $-0.047^{* * *}$ & \\
\hline & \multicolumn{2}{|c|}{ NCDs (dummy $=1$ if any) } & 0.528 & $0.982^{* *}$ & $1.188^{* * *}$ & \\
\hline & \multicolumn{2}{|c|}{ Exercise (h. per week) } & $-0.200^{\star *}$ & 0.049 & $-0.148^{* * *}$ & \\
\hline & \multicolumn{2}{|c|}{ Interest (in healt. nutr. 0- } & 0.081 & \multirow[t]{2}{*}{$0.280^{* *}$} & \multirow[t]{2}{*}{$0.248^{* * *}$} & \\
\hline & \multicolumn{2}{|r|}{ 10) } & & & & \\
\hline & & Constant & $-3.265^{\star *}$ & -0.464 & 0.562 & \\
\hline \multirow{9}{*}{ WTP $(€)$} & & $9.59^{*}$ & $12.42^{*}$ & \multirow{2}{*}{\multicolumn{2}{|c|}{$\begin{array}{c}2.35 \\
\quad(-14.17 \text { to } 18.56)\end{array}$}} & $2.78^{* \star}$ \\
\hline & Pers. 2 & $\begin{array}{c}(-1.20 \text { to } \\
20.38)\end{array}$ & (5.27 to 19.57$)$ & & & $(0.45$ to 5.11$)$ \\
\hline & & $23.53^{* * *}$ & $26.04^{* \star *}$ & \multirow{2}{*}{\multicolumn{2}{|c|}{$\begin{array}{c}124.85^{* * *} \\
(29.55 \text { to } \\
220.16)\end{array}$}} & $2.90^{* *}$ \\
\hline & Pers. 3 & (9.78 to 37.29$)$ & $\begin{array}{c}(17.40 \text { to } \\
34.68)\end{array}$ & & & (0.29 to 5.51$)$ \\
\hline & & $23.32^{* * *}$ & $27.49^{\star * *}$ & \multicolumn{2}{|c|}{$138.78^{* * *}$} & -0.94 \\
\hline & Pers. 4 & $\begin{array}{c}\text { (11.09 to } \\
35.56)\end{array}$ & $\begin{array}{c}\text { (19.35 to } \\
35.63)\end{array}$ & \multicolumn{2}{|c|}{$\begin{array}{l}\text { (40.27 to } \\
237.28)\end{array}$} & $(-1.51$ to 3.40$)$ \\
\hline & & $24.27^{* \star *}$ & $-3.43^{\star \star \star}$ & \multirow{2}{*}{\multicolumn{2}{|c|}{$\begin{array}{c}-9.28 \\
(-24.64 \text { to } 6.08)\end{array}$}} & $-4.53^{\star \star \star}$ \\
\hline & Dig. & $\begin{array}{c}(12.47 \text { to } \\
36.07)\end{array}$ & $(-6.72$ to -0.15$)$ & & & $(-6.15$ to -2.90$)$ \\
\hline & $\begin{array}{r}\text { Exerc. } \\
\text { Inc. }\end{array}$ & $\begin{array}{c}7.72^{* *} \\
(1.02 \text { to } 14.41)\end{array}$ & $\begin{array}{c}30.42^{\star *} \\
(24.68 \text { to } \\
36.17)\end{array}$ & \multicolumn{2}{|c|}{$\begin{array}{c}22.09^{*} \\
(0.68 \text { to } 44.85)\end{array}$} & $\begin{array}{c}-0.93 \\
(-2.72 \text { to }-0.85)\end{array}$ \\
\hline
\end{tabular}

Attr.: Attributes, WTP: Willingness to pay, NCDs: non-communicable diseases ${ }^{*}: p$-value $<0.10,{ }^{* *}: p$-value $<0.05,{ }^{* * *}$ : $p$-value < 0.01. Notes: the first section shows the coefficients for the alternative-specific (attributes and levels) variables. The first level of each attribute is constricted to zero and omitted. The second section (characteristics) shows the coefficients for the case-specific (membership) variables. The case-specific coefficients can be interpreted as variables that increase the probability of belonging to one class with respect to the reference class, Class 4 (check Table 5 for more perspective). The last section is an estimation of the willingness to pay for each class for each alternative-specific variable. The WTP is presented as (WTP mean)/((95\% Cl)).

Class 2 has significant preferences for advanced levels of personalisation, but with only a small WTP for level 4 over 3 (about $1 €$ ). They tend to prefer a physical on-site delivery of the personalised nutrition service, and value an integrated physical activity training plan. They have the second highest price elasticity of demand which might be due to having the second lowest income (Table 5). Class 2 is relatively likely to have an NCD, has the highest a priori interest in the service, and the highest level of physical activity. These respondents are willing to pay up to $27 €(19-35 €)$ for the personalisation level 4 (compared to no personalisation) and $30 €$ for the training plan. They were willing to acquire $45 \%$ of the chosen options.

Table 5. Case-specific characteristics by class in the latent class logit

\begin{tabular}{|c|c|c|c|c|c|c|}
\hline Class & Income & Education & Age & NCDs & Exercise & Interest \\
\hline 1 & 4.04 & 15.53 & 41.44 & 0.16 & 2.64 & 7.78 \\
\hline 2 & 3.72 & 13.72 & 43.55 & 0.27 & 4.68 & 8.43 \\
\hline 3 & 4.21 & 14.22 & 39.32 & 0.27 & 3.12 & 8.27 \\
\hline 4 & 3.51 & 13.81 & 45.35 & 0.15 & 3.80 & 7.40 \\
\hline Total & 3.82 & 14.16 & 42.81 & 0.22 & 3.75 & 7.99 \\
\hline
\end{tabular}


Income (in 9 ranges - see table 2), education (in estimated years of education - assigning a number of years per level), NCDs (\% of people with one or more non-communicable diseases), exercise (mean hours per week), interest (mean from 0 to 10).

Class 3 is comprised of the individuals with the highest WTP from the personalisation levels 3 and 4. They were indifferent between the digital and on-site delivery format, while they had a moderate preference for the training plan and the most price-inelastic demand. This Class is formed of the wealthier people, with lower mean age, the highest prevalence of NCDs, relatively sedentary lifestyle and interested in the PN service. The mean willingness to pay for the level 3 and 4 of personalisation reaches 125 and $139 €$ respectively. They were the class with the highest willingness to acquire the selected options (50\%).

Class 4 (see Table 5) consists, compared with the sample mean, of individuals with lower income, older age, fewer NCDs, less interest in PN, and an average level of education and hours of exercise per week. The DCE responses show low preference for PN at any level. Class 4 also declared the lowest willingness to acquire the selected alternatives (38.52\%).

\subsection{Sensitivity analysis}

We conducted a sensitivity analysis to control for the estimated WTPs measured by respondents' purchase probabilities. To do this, we separated the consumers in two group. The first group contains consumers with higher purchase probability, i.e.: $>33 \%$. The second group contains all respondents with low purchase probability, $<34 \%$. For both groups, we estimated a random parameters logit model and their WTP. The results are presented in Table 6.

The group with a low purchase probability is willing to pay $40 \%$ lower than the sample average and $50 \%$ lower than the high purchase probability group. Thus, the purchase probability indicator is able to accurately classify consumers into high and low WTP.

Table 6. Sensitivity analysis WTP results.

\begin{tabular}{cccc}
\hline Attribute's level & Mean WTP & Low pp (\%) & High pp (\%) \\
\hline Personalisation: Level 2 & $4.4 €^{* * *}$ & $4.57 €^{* * *}$ & $5.60 €^{* * *}$ \\
Personalisation: Level 3 & $20.56 €^{* * *}$ & $13.90 €^{* * *}$ & $26.87 €^{* * *}$ \\
Personalisation: Level 4 & $21.94 €^{* * *}$ & $13.81 €^{* * *}$ & $31.36 €^{* * *}$ \\
Delivery format: Digital & $1.43 €^{*}$ & $2.33 €^{* *}$ & $0.50 €$ \\
Exercise routines included & $13.59 €^{* * *}$ & $8.80 €^{* * *}$ & $19.78 €^{* * *}$ \\
\hline $\begin{array}{l}\text { Low pp: low purchase probability (<33\%), High pp: high purchase probability }(\geq 33 \%), \text { Mean WTP (mean willingness } \\
\text { to pay from the mixed logit model estimated in this paper). }\end{array}$
\end{tabular}

\section{Discussion}

Our research suggests that the general public has a high degree of interest in personalised nutrition. We estimated WTP of around $20 €$ on average for what we describe as "level 3" personalisation that includes advice from a licensed nutritionist and blood tests, and respondents indicate they would pay a further $14 €$ for a package that includes an exercise program adapted to their physical condition. These prices are similar to subscription to apps with such features in 
the market-place. The preference for support and monitoring by a licenced nutritionist confirms previous work (29)(32).

Previous studies identified "supporters, neutrals, and unsupportive" groups by their ex-ante attitude to PN $(34,35)$. Our work goes further in explaining which types of people adopt these positions. The latent class model grouped participants into four clusters, and these might informally be labelled "tech-savvy neutrals", "sport-focused", "PN supporters", and "unsupportive".

The tech-savvy neutrals (Class 1 ) were characterised by people with a higher education level, sedentary lifestyle, and strong preferences for the digital format, but a relatively low utility coefficient for level 3 or 4 PN and relatively low WTP. This group might opt for a cheap and versatile digital version of a basic nutrition service, but do not seem interested in a high level of PN.

The sport-focused class (Class 2) were more interested in the physical activity plan than in PN per-se and preferred the on-site format. This group is characterised by the highest number of weekly sports hours ( +1 hour than the population average). This group showed the highest a priori interest in healthy nutrition and preference for the highest level of PN (as shown by the utility coefficient or part-worth) but their stated average WTP for the highest level $(27 €)$ would probably not cover the production cost of such a service.

Personalised nutrition supporters (Class 3) consist of people mainly interested in PN regardless of the other functionalities, exhibit the highest WTP, $138 €$ on average for the highest level of PN. This group was wealthier and younger than average, and with more pre-existing NCDs.

The "unsupportive" class (Class 4) showed little interest in any type of PN and extremely low WTP. The literature draws attention to out-of-pocket cost as a factor in non-support $(30,37)$. This study adds important nuance to these findings. Our study finds that this group has the lowest income and lowest prevalence of NCDs, as well as high levels of existing physical activity. Hence it is likely that these individuals do not perceive any need for further motivation, as well as lacking the disposable income to pay for it.

Previous literature found that health improvement and disease prevention are strong motivators for adopting personalised interventions (29) (30). We found that supporters (class 3 ) have higher NCD rates, as well as higher income. The union of these factors might make this group important target consumers for any commercial firm that might be considering developing this service. Consumers in class 2 also have relatively high NCD rates, but lower income. These consumers show preference for PN but not high WTP. Further research might investigate whether this group might adopt and benefit from PN if it were offered as a subsidised service.

\subsection{Limitations}


Our results are based on respondents from Spain, and further research might investigate whether the relationship between preferences and respondent's characteristics might be generalisable to other similar countries.

Previous studies have highlighted the role of data privacy $(26,27,29,32,33,36)$, though we did not examine these issues as trade-offs in the DCE. Studies show that consumers in general may state that they are concerned about data privacy, but in many cases fail to act accordingly to protect their own data, tending instead to prefer the immediate benefits and convenience of online apps ('privacy paradox') (54). PN apps collect and store individual data related to health, raising additional ethical concerns that we are unable to cover here.

In this study we did not offer respondents an 'opt-out' option. Prior studies found that US households were willing to pay between $4 \$$ and $6 \$$ per month in telehealth (55), while our study estimates a greater value. When we set WTP for those who gave a low probability of making a purchase, WTP reduces, indicating that the purchase probability variable is highly correlated with the WTP. Consequently, those consumers captured by the low purchase probability analysis are likely to opt-out, and interventions that aim to include this group should consider low prices.

Our study has examined consumer preference for the attributes of a hypothetical PN service, but has not examined why consumers would want to adopt it. Health promotion is only one reason and it is likely that diverse motives are at play, including cultural and peer-group factors, body appearance, auto-esteem, and so on. Likewise, an app is simply a tool and its effectiveness will depend on how it is deployed. Any proposed intervention built around an app should be formally evaluated, preferably in the context of a randomised controlled study.

\section{Conclusions}

The discrete choice experiment we have conducted has shown that there may be a private market for high levels of personalised nutrition among about a fifth of consumers (Class 3 ), and there may be interest in adopting high levels of personalised nutrition in a further one-third of adults if the price were low enough (Class 2). Class 1 (17\% of adults) perceive some value in the advice of a professional nutritionist, but not in very intensive levels of testing. There is not much interest in personalised nutrition interventions among the remaining adults. Of relevance for public health decision-makers, this means that just over half of adults currently perceive some individual benefit in a high level of PN, which may justify some degree of public subsidy in investment and delivery of such a service. Further work might investigate whether these groups might be encouraged with appropriate information, or alternatively, do not require or need such a service.

Conflicts of interest: the authors have no conflicts of interest.

Funding: This project has received funding from the European Union's Horizon 2020 research and innovation programme under grant agreement No 816303 (STANCE4HEALTH). 
Acknowledgements: We wish to thank the entire Stance4Health team for their support, Professors Joan Gil and Miguel A. Negrin for their helpful suggestions at the EEconAES Workshop and AESEC session, and Daniel Hinojosa for providing a professional nutritionist's point of view.

\section{Link to the article:}

Data and Stata code: http://dx.doi.org/10.17632/kh2btj3btj.1

\section{References}

1. World Health Organization. Deaths from NCDs [Internet]. 2015. Available from: https://www.who.int/gho/ncd/mortality_morbidity/ncd_total_text/en/

2. Australian Institute of Health and Welfare. Chronic diseases and associated risk factors in Australia, 2006. Available from: https://www.aihw.gov.au/reports/chronicdisease/chronic-diseases-risk-factors-australia-2006/contents/table-of-contents

3. World Health Organization. Global Status Report On Noncommunicable Diseases. 2014. Available from: https://www.who.int/nmh/publications/ncd-status-report-2014/en/

4. World Economic Forum, Harvard School of Public Health. The Global Economic Burden of Non-communicable Diseases. 2011. Available from: http://mi.umsa.edu.ar/miumsa/downloads/materiales/gutman.3739/Cuadernillo_2015_- 
Practica_de_la_Traduccion_Oral_I.pdf\%5Cnhttp://www3.weforum.org/docs/WEF_Harv ard_HE_GlobalEconomicBurdenNonCommunicableDiseases_2011.pdf

5. World Health Organization. WHO's Human Genetics areas of work. World Health Organization; 2016. Available from: https://www.who.int/genomics/about/commondiseases/en/

6. Willett WC. Diet and health: What should we eat? Science (80- ). 1994;264(5158):532-7.

7. Hu FB. Dietary pattern analysis: A new direction in nutritional epidemiology. Curr Opin Lipidol. 2002;13(1):3-9.

8. Minich DM, Bland JS. Personalized lifestyle medicine: Relevance for nutrition and lifestyle recommendations. Sci World J. 2013;2013.

9. Mozaffarian D. Dietary and Policy Priorities for Cardiovascular Disease, Diabetes, and Obesity. Circulation. 2016;133(2):187-225.

10. Joost HG, Gibney MJ, Cashman KD, Görman U, Hesketh JE, Mueller M, et al. Personalised nutrition: Status and perspectives. Vol. 98, British Journal of Nutrition. Cambridge University Press; 2007. p. 26-31.

11. Sonnenburg JL, Bäckhed F. Diet-microbiota interactions as moderators of human metabolism. Nature. 2016;535(7610):56-64.

12. Ordovas JM, Ferguson LR, Tai ES, Mathers JC. Personalised nutrition and health. BMJ. 2018;361.

13. Zeevi D, Korem T, Zmora N, Israeli D, Rothschild D, Weinberger A, et al. Personalized Nutrition by Prediction of Glycemic Responses. Cell. 2015;163(5):1079-94.

14. Ley RE, Turnbaugh PJ, Klein S, Gordon Jl. Microbial ecology: Human gut microbes associated with obesity. Nature. 2006 Dec 21;444(7122):1022-3.

15. David LA, Maurice CF, Carmody RN, Gootenberg DB, Button JE, Wolfe BE, et al. Diet rapidly and reproducibly alters the human gut microbiome. Nature. 2014;505(7484):55963.

16. Smart Technologies for personAlised Nutrition and Consumer Engagement | Stance4Health Project | H2020 | CORDIS | European Commission. Available from: https://cordis.europa.eu/project/id/816303

17. Zhao J, Freeman B, Li M. Can mobile phone apps influence people's health behavior change? An evidence review. Vol. 18, Journal of Medical Internet Research. Journal of Medical Internet Research; 2016

18. Bol N, Helberger N, Weert JCM. Differences in mobile health app use: A source of new digital inequalities? Inf Soc. 2018 May 27 [cited 2020 Sep 8];34(3):183-93.

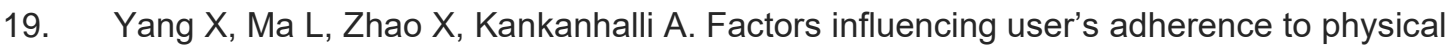
activity applications: A scoping literature review and future directions. Vol. 134, International Journal of Medical Informatics. Elsevier Ireland Ltd; 2020. p. 104039.

20. George W Torrance. Measurement of Health State Utilities for Economic Appraisal. J Health Econ. 1986;5.

21. Hausman J. Contingent valuation: From dubious to hopeless. J Econ Perspect. 2012 Sep;26(4):43-56.

22. Soekhai V, de Bekker-Grob EW, Ellis AR, Vass CM. Discrete Choice Experiments in 
Health Economics: Past, Present and Future [Internet]. Vol. 37, PharmacoEconomics. 2019. p. 201-26.

23. Baltas G, Doyle P. Random utility models in marketing research: A survey. J Bus Res. 2001 Feb 1;51(2):115-25.

24. Michie S, Yardley L, West R, Patrick K, Greaves F. Developing and evaluating digital interventions to promote behavior change in health and health care: Recommendations resulting from an international workshop. Vol. 19, Journal of Medical Internet Research. Journal of Medical Internet Research; 2017 [cited 2020 Jul 27]. p. e232.

25. Haugen HA, Tran Z V., Wyatt HR, Barry MJ, Hill JO. Using Telehealth to Increase Participation in Weight Maintenance Programs**. Obesity 2007. 15(12):3067-77.

26. Poínhos R, van der Lans IA, Rankin A, Fischer ARH, Bunting B, Kuznesof S, et al. Psychological Determinants of Consumer Acceptance of Personalised Nutrition in 9 European Countries. Lucidi F, editor. PLoS One [Internet]. 2014. 9(10):e110614.

27. Fischer ARH, Berezowska A, Van Der Lans IA, Ronteltap A, Rankin A, Kuznesof S, et al. Willingness to pay for personalised nutrition across Europe. Eur J Public Health. 2016;26(4):640-4.

28. Mustapa MAC, Amin L, Frewer LJ. Predictors of stakeholders' intention to adopt nutrigenomics. Genes Nutr. 2020 Sep 22 [cited 2021 Feb 1];15(1):1-15.

29. Vallée Marcotte B, Cormier H, Garneau V, Robitaille J, Desroches S, Vohl M-C. Nutrigenetic Testing for Personalized Nutrition: An Evaluation of Public Perceptions, Attitudes, and Concerns in a Population of French Canadians. Lifestyle Genomics 2018;11(3-6):155-62.

30. Veldwijk J, Lambooij MS, Van Gils PF, Struijs JN, Smit HA, De Wit GA. Type 2 diabetes patients' preferences and willingness to pay for lifestyle programs: A discrete choice experiment. BMC Public Health [Internet]. 2013;13(1):1099.

31. Mattei J, Alfonso C. Strategies for Healthy Eating Promotion and Behavioral Change Perceived as Effective by Nutrition Professionals: A Mixed-Methods Study. Front Nutr. 2020

32. Rankin A, Kuznesof S, Frewer LJ, Orr K, Davison J, De Almeida MDV, et al. Public perceptions of personalised nutrition through the lens of Social Cognitive Theory. J Health Psychol [Internet]. 2017.

33. Feng-Gu E, Everett J, Brown RCH, Maslen H, Oakley J, Savulescu J. Prospective Intention-Based Lifestyle Contracts: mHealth Technology and Responsibility in Healthcare. Heal Care Anal. 2021.

34. Determann D, Lambooij MS, Gyrd-Hansen D, de Bekker-Grob EW, Steyerberg EW, Heldoorn M, et al. Personal health records in the Netherlands: Potential user preferences quantified by a discrete choice experiment. J Am Med Informatics Assoc. 2017

35. Foltz JL, Harris DM, Blanck HM. Support among U.S. adults for local and state policies to increase fruit and vegetable access. Am J Prev Med. 2012

36. Stewart-Knox B, Rankin A, Kuznesof S, Poínhos R, Vaz De Almeida MD, Fischer A, et al. Promoting healthy dietary behaviour through personalised nutrition: Technology push or technology pull? In: Proceedings of the Nutrition Society. Cambridge University Press; 2015 
37. Rankin A, Bunting BP, Poínhos R, Van Der Lans IA, Fischer ARH, Kuznesof S, et al. Food choice motives, attitude towards and intention to adopt personalised nutrition. Public Health Nutr. 2018

38. Molema C, Veldwijk J, Wendel-Vos W, De Wit A, van de Goor I, Schuit J. Chronically ill patients' preferences for a financial incentive in a lifestyle intervention. Results of a discrete choice experiment. PLoS One. 2019

39. Bridges JFP, Hauber AB, Marshall D, Lloyd A, Prosser LA, Regier DA, et al. Conjoint Analysis Applications in Health-a Checklist: A Report of the ISPOR Good Research Practices for Conjoint Analysis Task Force. Value Heal. 2011.

40. Street DJ, Burgess L, Louviere JJ. Quick and easy choice sets: Constructing optimal and nearly optimal stated choice experiments. Int J Res Mark. 2005;22(4):459-70.

41. Pittler MH, Ernst E. Dietary supplements for body-weight reduction: A systematic review. Vol. 79, American Journal of Clinical Nutrition. American Society for Nutrition; 2004

42. Hole AR, Hole, Arne. DCREATE: Stata module to create efficient designs for discrete choice experiments. 2017 Aug 25;

43. Zwerina K, Huber J, Kuhfeld WF. A general method for constructing efficient choice designs. Durham, NC Fuqua Sch Business, Duke Univ. 1996;

44. Johnson FR, Lancsar E, Marshall D, Kilambi V, Mühlbacher A, Regier DA, et al. Constructing experimental designs for discrete-choice experiments: Report of the ISPOR conjoint analysis experimental design good research practices task force. Value Heal. 2013 Jan;16(1):3-13.

45. Janssen EM, Hauber AB, Bridges JFP. Conducting a Discrete-Choice Experiment Study Following Recommendations for Good Research Practices: An Application for Eliciting Patient Preferences for Diabetes Treatments. Value Heal. 2018 Jan 1;21(1):59-68.

46. Johnson R, Orme B. Getting the Most from CBC [Internet]. 2003 [cited 2021 Feb 15]. Available from: www.sawtoothsoftware.com

47. Lancsar E, Louviere J. Conducting Discrete Choice Experiments to Inform Healthcare Decision Making. Pharmacoeconomics [Internet]. 2008; 26(8):661-77.

48. Domencich TA, McFadden D. URBAN TRAVEL DEMAND - A BEHAVIORAL ANALYSIS. 1975;

49. Hauber AB, González JM, Groothuis-Oudshoorn CGM, Prior T, Marshall DA, Cunningham C, et al. Statistical Methods for the Analysis of Discrete Choice Experiments: A Report of the ISPOR Conjoint Analysis Good Research Practices Task Force. Value Heal. 2016.

50. Maddala GS. Limited-Dependent and Qualitative Variables in Econometrics. 1st ed. Cambridge: Cambridge University Press; 1983.

51. Train KE. Discrete choice methods with simulation, second edition. Vol. 9780521766555 , Discrete Choice Methods with Simulation, Second Edition. Cambridge University Press; 2009. 1-388 p.

52. Yoo H II. Iclogit2: An enhanced module to estimate latent class conditional logit models. 2019 Nov.

53. McFadden D. Quantitative Methods for Analyzing Travel Behaviour of Individuals: Some Recent Developments. Cowles Found Discuss Pap [Internet]. 1977. 
54. Kokolakis S. Privacy attitudes and privacy behaviour: A review of current research on the privacy paradox phenomenon. Vol. 64, Computers and Security. Elsevier Ltd; 2017. p. 122-34.

55. Chang J, Savage SJ, Waldman DM. Estimating Willingness to Pay for Online Health Services with Discrete-Choice Experiments. Appl Health Econ Health Policy. 2017 Aug 1];15(4):491-500.

\section{Supplementary material}

Section A. Literature review search terms

Search terms in Pubmed: ((personalised nutrition) OR (personalized nutrition)) AND ((health) OR (Mobile Health) OR (eHealth)) AND ((willingness to pay) OR (discrete choice experiment)) AND (disease prevention)

Search terms in Scopus: ( ( personalised AND nutrition ) OR ( personalized AND nutrition ) ) AND ( ( health) OR ( mobile AND health) OR ( ehealth)) AND ( ( willingness AND to AND pay) OR (discrete AND choice AND experiment)) AND (disease AND prevention) AND ( LIMIT-TO ( DOCTYPE, "ar") ) AND ( LIMIT-TO ( SUBJAREA, "MEDI" ) OR LIMITTO ( SUBJAREA, "ECON" ) )

Fig. 2. Flow chart for the results of the literature review 


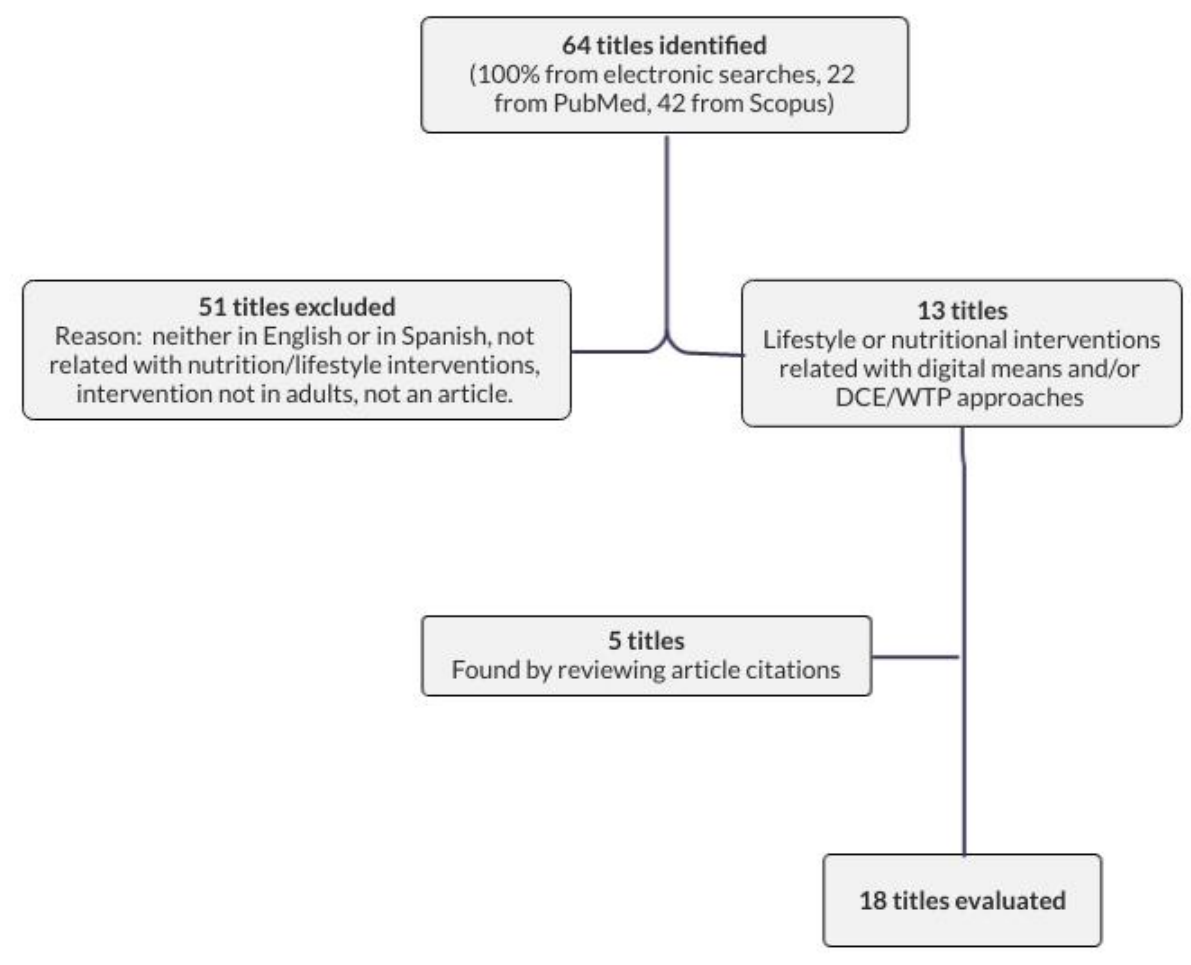

Table 7. Summary of findings of articles related to personalised nutrition

\begin{tabular}{|c|c|c|c|c|c|}
\hline Ref. & Population & Intervention & Control & Type of study & $\begin{array}{l}\text { Brief summary of } \\
\text { findings }\end{array}$ \\
\hline (1) & $\begin{array}{l}\text { Spanish adults } \\
\text { (general } \\
\text { population) }\end{array}$ & $\begin{array}{l}\text { Yogourth with } \\
\text { nutritional claims }\end{array}$ & - & $\begin{array}{l}\text { Discrete Choice } \\
\text { Experiment }\end{array}$ & $\begin{array}{l}\text { Three population } \\
\text { subgroups: one } \\
\text { focused on health } \\
\text { and nutrition, one } \\
\text { focused only on } \\
\text { health, and one } \\
\text { indifferent to health } \\
\text { and nutrition. }\end{array}$ \\
\hline (2) & $\begin{array}{l}\text { Dutch adults with } \\
\text { diabetes mellitus } \\
\text { type } 2\end{array}$ & $\begin{array}{l}\text { Lifestyle } \\
\text { intervention } \\
\text { program with } 5 \\
\text { attributes (food, } \\
\text { exercise, } \\
\text { monitoring, } \\
\text { outcomes, and } \\
\text { price) }\end{array}$ & - & $\begin{array}{l}\text { Discrete Choice } \\
\text { Experiment }\end{array}$ & $\begin{array}{l}\text { The potential } \\
\text { participation rate of } \\
\text { chronic patients in a } \\
\text { lifestyle intervention } \\
\text { ranges between } 50 \\
\text { and } 60 \% \text {. }\end{array}$ \\
\hline (3) & $\begin{array}{l}\text { Representative } \\
\text { sample from nine } \\
\text { European } \\
\text { countries }\end{array}$ & $\begin{array}{l}\text { Food selection } \\
\text { depending on nine } \\
\text { factors. }\end{array}$ & - & $\begin{array}{l}\text { Survey study: } \\
\text { Food Choice } \\
\text { Questionnaire }\end{array}$ & $\begin{array}{l}\text { Out-of-pocket costs } \\
\text { might determine the } \\
\text { attitude towards PN. }\end{array}$ \\
\hline (4) & $\begin{array}{l}\text { Dutch adults with } \\
\text { diabetes mellitus } \\
\text { type } 2 \text { or } \\
\text { cardiovascular } \\
\text { disease }\end{array}$ & $\begin{array}{l}\text { Incentives for } \\
\text { achieving the } \\
\text { goals of a lifestyle } \\
\text { intervention }\end{array}$ & - & $\begin{array}{l}\text { Discrete Choice } \\
\text { Experiment }\end{array}$ & $\begin{array}{l}\text { Patients are willing } \\
\text { to accept a financial } \\
\text { incentive only if they } \\
\text { accomplish the } \\
\text { intervention. }\end{array}$ \\
\hline (5) & $\begin{array}{l}\text { Sample from the } \\
\text { panel of the dutch } \\
\text { federation of } \\
\text { patients and } \\
\text { consumer } \\
\text { organizations }\end{array}$ & $\begin{array}{l}\text { Personal health } \\
\text { records use }\end{array}$ & - & $\begin{array}{l}\text { Discrete Choice } \\
\text { Experiment }\end{array}$ & $\begin{array}{l}\text { Three groups } \\
\text { depending on their } \\
\text { attitude towards } \\
\text { personal health } \\
\text { records (supporters, } \\
\text { neutrals, and } \\
\text { unsupportive). }\end{array}$ \\
\hline (6) & $\begin{array}{l}\text { Data from the } \\
2008 \text { HealthStyles } \\
\text { survey of the US }\end{array}$ & $\begin{array}{l}\text { Local and state } \\
\text { policies promoting } \\
\text { fruit and vegetable } \\
\text { consume }\end{array}$ & - & Qualitative survey & $\begin{array}{l}\text { The majority of } \\
\text { consumers support } \\
\text { the policies. }\end{array}$ \\
\hline
\end{tabular}




\begin{tabular}{|c|c|c|c|c|c|}
\hline (7) & $\begin{array}{l}\text { US adults who } \\
\text { completed a 24- } \\
\text { week behaviour } \\
\text { weight loss plan }\end{array}$ & $\begin{array}{l}\text { Telehealth weight } \\
\text { manteinance } \\
\text { programme }\end{array}$ & $\begin{array}{l}\text { Tradition } \\
\text { al weight } \\
\text { manteina } \\
\text { nce } \\
\text { program } \\
\text { me / No } \\
\text { program } \\
\text { me }\end{array}$ & $\begin{array}{l}\text { Quasi- } \\
\text { experimental study }\end{array}$ & $\begin{array}{l}\text { Users rate the } \\
\text { experience using a } \\
\text { telehealth } \\
\text { programme as } \\
\text { positive and } \\
\text { convenient. } \\
\text { Telehealth } \\
\text { programmes are } \\
\text { effective in achieving } \\
\text { an enhancement of } \\
\text { the user's health. }\end{array}$ \\
\hline$(8)$ & $\begin{array}{l}\text { Overweight or } \\
\text { obese cohort of } \\
\text { patients with } \\
\text { diabetes and } \\
\text { cardiovascular } \\
\text { risk }\end{array}$ & $\begin{array}{l}\text { Online diabetes } \\
\text { prevention } \\
\text { programme }\end{array}$ & $\begin{array}{l}\text { Usual } \\
\text { care }\end{array}$ & $\begin{array}{l}\text { Markov model } \\
\text { (cost-effectiveness } \\
\text { study) }\end{array}$ & $\begin{array}{l}\text { The online diabetes } \\
\text { prevention } \\
\text { programme might be } \\
\text { cost-effective } \\
\text { solution }\end{array}$ \\
\hline$(9)$ & $\begin{array}{l}\text { People with body } \\
\text { mass index higher } \\
\text { than } 25 \mathrm{~kg} / \mathrm{m} 2 \text {. }\end{array}$ & $\begin{array}{l}\text { Diet and physical } \\
\text { activity } \\
\text { prescription } \\
\text { algorithm via } \\
\text { mobile app (12 } \\
\text { weeks) }\end{array}$ & - & $\begin{array}{l}\text { Quasi- } \\
\text { experimental } \\
\text { design }\end{array}$ & $\begin{array}{l}\text { Body weight } \\
\text { decreased and other } \\
\text { measures improved. }\end{array}$ \\
\hline (10) & $\begin{array}{l}\text { Representative } \\
\text { sample from } \\
\text { French Canadian } \\
\text { population }\end{array}$ & $\begin{array}{l}\text { Attitudes and } \\
\text { perceptions } \\
\text { towards } \\
\text { nutrigenetics. }\end{array}$ & - & Qualitative survey & $\begin{array}{l}\text { Consumers are } \\
\text { interested in the } \\
\text { extensive use of } \\
\text { nutrigenetics but } \\
\text { there are concerns } \\
\text { about data privacy. }\end{array}$ \\
\hline (11) & $\begin{array}{l}\text { General public } \\
\text { from the United } \\
\text { Kingdom }\end{array}$ & $\begin{array}{l}\text { Attitudes towards } \\
\text { individual } \\
\text { responsibility and } \\
\text { lifestyle } \\
\text { intervention }\end{array}$ & - & Qualitative survey & $\begin{array}{l}\text { There is the general } \\
\text { believe that people } \\
\text { have a duty to look } \\
\text { after their own } \\
\text { health. }\end{array}$ \\
\hline (12) & $\begin{array}{l}\text { Representative } \\
\text { sample from } 9 \\
\text { european } \\
\text { countries }\end{array}$ & $\begin{array}{l}\text { Determinants of } \\
\text { adoption of } \\
\text { personalised } \\
\text { nutrition }\end{array}$ & - & Qualitative survey & $\begin{array}{l}\text { The attitudes } \\
\text { towards } \\
\text { personalised } \\
\text { nutrition are mainly } \\
\text { driven by the } \\
\text { expected outcome. }\end{array}$ \\
\hline (13) & $\begin{array}{l}\text { Representative } \\
\text { sample from } 9 \\
\text { european } \\
\text { countries }\end{array}$ & $\begin{array}{l}\text { Evidence } \\
\text { collection from the } \\
\text { Food4Me project }\end{array}$ & - & $\begin{array}{l}\text { Qualitative and } \\
\text { quantitative survey }\end{array}$ & $\begin{array}{l}\text { The perceived } \\
\text { benefit increased the } \\
\text { intention to undergo } \\
\text { a personalised } \\
\text { nutrition intervention. }\end{array}$ \\
\hline (14) & $\begin{array}{l}\text { Two focus groups } \\
\text { in different regions } \\
\text { of the UK }\end{array}$ & $\begin{array}{l}\text { Attitudes and } \\
\text { perceptions } \\
\text { towards } \\
\text { personalised } \\
\text { nutrition }\end{array}$ & - & $\begin{array}{l}\text { Qualitative results } \\
\text { from discussions }\end{array}$ & $\begin{array}{l}\text { Monitoring and } \\
\text { coaching increase } \\
\text { the probabilities that } \\
\text { the intervention is } \\
\text { effective. Paying for } \\
\text { the personalised } \\
\text { nutrition intervention } \\
\text { is an indicator of the } \\
\text { willingness to } \\
\text { undergo it. }\end{array}$ \\
\hline (15) & $\begin{array}{l}\text { Representative } \\
\text { population from } 9 \\
\text { European } \\
\text { countries }\end{array}$ & $\begin{array}{l}\text { WTP towards a } \\
\text { personalised } \\
\text { nutrition } \\
\text { intervention }\end{array}$ & - & $\begin{array}{l}\text { Contingent } \\
\text { valuation WTP } \\
\text { study }\end{array}$ & $\begin{array}{l}\text { In Europe, one third } \\
\text { of the population is } \\
\text { willing to pay for } \\
\text { personalised } \\
\text { nutrition (price found } \\
\text { to be around } € 30-40 \text { ) }\end{array}$ \\
\hline (16) & $\begin{array}{l}\text { Adults from } \\
\text { Malaysia (50\% } \\
\text { patients and } 50 \% \\
\text { healthcare } \\
\text { providers) }\end{array}$ & $\begin{array}{l}\text { Prediction of } \\
\text { willingness to } \\
\text { adopt } \\
\text { nutrigenomics }\end{array}$ & - & $\begin{array}{l}\text { Quantitative and } \\
\text { qualitative results } \\
\text { from survey } \\
\text { instrument }\end{array}$ & $\begin{array}{l}\text { The benefits / risk } \\
\text { balance is an } \\
\text { essential element in } \\
\text { the decision towards } \\
\text { the support or }\end{array}$ \\
\hline
\end{tabular}




\begin{tabular}{|c|c|c|c|c|c|}
\hline & & & & & $\begin{array}{l}\text { rejection of } \\
\text { nutrigenomics. }\end{array}$ \\
\hline (17) & $\begin{array}{l}\text { Nutritionists from } \\
\text { the College of } \\
\text { Nutritionists and } \\
\text { Dietitians of } \\
\text { Puerto Rico }\end{array}$ & $\begin{array}{l}\text { Strategies for } \\
\text { promotion of } \\
\text { behavioural } \\
\text { change in nutrition }\end{array}$ & - & $\begin{array}{l}\text { Qualitative survey } \\
\text { (open-ended } \\
\text { questions) }\end{array}$ & $\begin{array}{l}\text { A personalised } \\
\text { orientation is } \\
\text { important for the } \\
\text { dietary intervention } \\
\text { to be effective. }\end{array}$ \\
\hline (18) & $\begin{array}{l}\text { Representative } \\
\text { sample from the } \\
\text { US average } \\
\text { household }\end{array}$ & $\begin{array}{l}\text { Willingness to pay } \\
\text { for telehealth } \\
\text { services }\end{array}$ & - & $\begin{array}{l}\text { Discrete Choice } \\
\text { Experiment }\end{array}$ & $\begin{array}{l}\text { The mean US } \\
\text { household was } \\
\text { willing to pay } 5 \$ \text { for } \\
\text { accessing online } \\
\text { health services. The } \\
\text { mean price } \\
\text { increased slightly for } \\
\text { households with } \\
\text { higher oportunitu } \\
\text { costs for the } \\
\text { telehealth } \\
\text { programme. }\end{array}$ \\
\hline
\end{tabular}

Section B. Design details First pilot test

In the Google Play store, we searched for key terms in Spanish such as nutrition (nutrición), diet (dieta), personalised nutrition (nutrición personalizada), and nutritional recommendations (recomendaciones nutricionales). By default, search results sort applications by user rating and number of downloads, so we downloaded the apps in the list in order and examined them one by one. After downloading an app, we signed up with a new user, checked if the app had different versions, took note of the price, and visited the webpage (if features were not clearly explained in the app) to examine all the functionalities offered in the app. Many of the apps we reviewed were exact copies of apps we had already reviewed but branded under a different name. When we detected this issue, we deleted the app and downloaded the next one in the list. After 5 downloads with no new results (due to copied applications or applications with 
virtually the same functionalities as above), we changed the key term. When we used all the key terms above, we considered achieved saturation. Thus, we found 9 different apps (15 different versions and up to 20 different functionalities) whose names are listed in Table B1.

Table 8. List of reviewed apps.

\begin{tabular}{|c|c|c|c|}
\hline App name & Version & Price & Description \\
\hline \multirow{3}{*}{$\begin{array}{l}\text { Nootric } \\
\text { (https://www.nootric.es/) }\end{array}$} & V.1. & $0 € /$ month & $\begin{array}{l}\text { Weekly menus and limited } \\
\text { recipes }\end{array}$ \\
\hline & V.2. & $9.99 € /$ month & $\begin{array}{l}\text { Unlimited menus and recipes + } \\
\text { nutritionist follow-up }\end{array}$ \\
\hline & V.3. & $23 € /$ month & $\begin{array}{l}\text { Unlimited menus and recipes + } \\
\text { nutritionist follow-up + diet } \\
\text { personalisation }\end{array}$ \\
\hline $\begin{array}{l}\text { Fitia } \\
\text { (https://www.fitiaapp.com/) }\end{array}$ & - & $7 € /$ month & $\begin{array}{l}\text { Personalisation based on age, } \\
\text { weight, height, sporting habits }+ \\
\text { shopping list functionality + } \\
\text { virtual follow-up }\end{array}$ \\
\hline \multirow[b]{2}{*}{$\begin{array}{l}\text { Yazio } \\
\text { (https://www.yazio.com/) }\end{array}$} & V.1 & $0 € /$ month & $\begin{array}{l}\text { Personalisation based on age, } \\
\text { height, weight and goal of the } \\
\text { diet }\end{array}$ \\
\hline & V.2. & $3 € /$ month & $\begin{array}{l}\text { Personalisation based on age, } \\
\text { height, weight and goal of the } \\
\text { diet + nutritional plan and fast } \\
\text { planning + compatible with } \\
\text { smart bands and smartwatches }\end{array}$ \\
\hline \multirow{2}{*}{$\begin{array}{l}\text { Lifesum } \\
\text { (https://lifesum.com/) }\end{array}$} & V.1. & $0 € /$ month & $\begin{array}{l}\text { Personalisation based on age, } \\
\text { height, weight, food diary }\end{array}$ \\
\hline & V.2. & $8 € /$ month & $\begin{array}{l}\text { Personalisation based on age, } \\
\text { height, weight, food diary + } \\
\text { menus and recipes }\end{array}$ \\
\hline $\begin{array}{l}\text { FitMenCook } \\
\text { (https://fitmencook.com/) }\end{array}$ & - & $0 € /$ month & Recipes \\
\hline \multirow[b]{2}{*}{$\begin{array}{l}\text { MyFitnessPal } \\
\text { (https://www.myfitnesspal.com/) }\end{array}$} & V.1. & $0 € /$ month & $\begin{array}{l}\text { Calorie meter with a daily goal } \\
\text { of personalised macronutrients } \\
\text { share }\end{array}$ \\
\hline & V.2. & $9.99 € /$ month & $\begin{array}{l}\text { Calorie meter with a daily goal } \\
\text { of personalised macronutrients } \\
\text { share + nutrients panel + food } \\
\text { analysis + daily sport goals }\end{array}$ \\
\hline \multirow[b]{2}{*}{ Looselt! } & V.1. & $0 € /$ month & $\begin{array}{l}\text { Personalised weight loss plan, } \\
\text { sync health apps and } \\
\text { community support }\end{array}$ \\
\hline & V.2. & $3.33 € /$ month & $\begin{array}{l}\text { Personalised weight loss plan, } \\
\text { sync health apps and } \\
\text { community support + advanced } \\
\text { tracking, meal and exercise } \\
\text { planning, patterns and } \\
\text { celebrations. }\end{array}$ \\
\hline $\begin{array}{l}\text { MyNetDiary } \\
\text { (https://www.mynetdiary.com/) }\end{array}$ & - & $8.28 € /$ month & $\begin{array}{l}\text { Diet planning, food logging, } \\
\text { exercise tracking, weight } \\
\text { tracking }\end{array}$ \\
\hline $\begin{array}{l}\text { DietPoint } \\
\text { (http://www.dietpointed.com/) }\end{array}$ & - & $15 € /$ month & $\begin{array}{l}\text { Personalised diet based on } \\
\text { weight, age, height and goals. }\end{array}$ \\
\hline
\end{tabular}

With the information in the right column of Table 8 and the attributes and levels extracted from Fischer et al (15) (personalisation levels), we created an extensive list of functionalities. The functionalities were deleted if they were duplicated, reformulated if they were overlapping, and 
grouped according to their nature. Some of the functionalities were not used to create the attributes (compatibility with smart bands and smartwatches - it required a second party device, shopping list functionality - we wanted to keep the number of attributes as small as possible and we thought this was less relevant). Thus, we created the first classification with 5 attributes (the groups) and their levels (the functionalities) (Table 8).

Table 9. Attributes and levels specification in the first pretest

\begin{tabular}{lll}
\hline Attribute & Levels & \\
\hline $\begin{array}{l}\text { Personalisation level } \\
\text { (amount of information }\end{array}$ & Level 1 & Body size \\
collected to generate the & Level 2 & + suggestions for allergies / intolerances or other diets \\
tailored diet) & Level 3 & + daily caloric intake values \\
& Level 4 & + gut microbiota analysis \\
Follow-up (diet compliance & Yes & Monthly follow-up by a nutritionist \\
monitoring) & No & No follow-up \\
Training plan & Yes & Daily training plan based on the data of the user \\
(personalised based on the & No & No training plan \\
data of the user) & Yes & Step-by-step videos cooking the recipes in your diet \\
Recipes video-tutorials & Yes & Nacilitate compliance \\
with the diet) & No & No video-tutorials \\
& $10 €$ & $10 € /$ month \\
Price (monthly amount) & $20 €$ & $20 € /$ month \\
& $30 €$ & $30 € /$ month \\
& $40 €$ & $40 € /$ month \\
\hline
\end{tabular}

The "personalisation level" attribute was identified from literature (Fischer et al. (15)) and "follow-up", "training plan" and "recipes" were identified from the apps review. The price attribute arises from a combination of the prices of the reviewed apps (up to $23 € /$ month) and Fischer et al. (15) (30€/month).

We did not include a price of $0 € /$ month because we only consider scenarios in which the costs of the service are covered without considering third party factors such as advertising or free trials, which we could not satisfactorily include in our DCE.

We included a fourth level of $40 € /$ month, which seemed reasonable to our clinical colleagues.

With the above attributes and levels selection, we created a $4^{2} \times 2^{3}$ optimal design (19) with 16 choice sets per respondent. We presented the design to an $\mathrm{N}=40$ convenience sample via an online survey.

\section{Second pilot test}

With the pilot test results, we collected feedback from respondents and attended a Health Economics forum. Respondents' opinions led us to reduce the number of choice sets that each respondent answered, separating the experimental design into two blocks. In the Health Economics forum, some colleagues pointed out that we should include a "delivery format" 
attribute (on-site or digital) and a "supplements" attribute (to include them or not in the diet). Besides, the "personalisation" attribute was reformulated with the help of a nutritionist working in the Stance4Health project. Finally, we decided to remove the "recipes" attribute due to its low part-worth in the pilot test. Once the changes were made, we got the attributes and levels selection in Table 10.

Table 10. Second selection of attributes and levels.

\begin{tabular}{|c|c|c|}
\hline Attribute & Levels & \\
\hline \multirow{4}{*}{$\begin{array}{l}\text { Personalisation level } \\
\text { (amount of information } \\
\text { collected to generate the } \\
\text { tailored diet) }\end{array}$} & Level 1 & Healthy suggestions and nutritional education \\
\hline & Level 2 & $\begin{array}{l}\text { Personalised diet based on age, weight, and } \\
\text { height. }\end{array}$ \\
\hline & Level 3 & $\begin{array}{l}\text { Personalised diet based on age, weight, height, } \\
\text { sports habits, and blood test. }\end{array}$ \\
\hline & Level 4 & $\begin{array}{l}\text { Personalised diet based on age, weight, height, } \\
\text { sports habits, blood test, and gut microbiota } \\
\text { analysis. }\end{array}$ \\
\hline \multirow{2}{*}{$\begin{array}{l}\text { Delivery format (of } \\
\text { service provision) }\end{array}$} & On-site & Service provided in a physical place \\
\hline & Digital & Service provided via mobile phone and webpage \\
\hline \multirow{2}{*}{$\begin{array}{l}\text { Follow-up (diet } \\
\text { compliance monitoring) }\end{array}$} & Yes & Monthly follow-up by a nutritionist \\
\hline & No & No follow-up \\
\hline \multirow{2}{*}{$\begin{array}{l}\text { Training plan } \\
\text { (personalised based on } \\
\text { the data of the user) }\end{array}$} & Yes & Daily training plan based on the data of the user \\
\hline & No & No training plan \\
\hline \multirow{2}{*}{$\begin{array}{l}\text { Supplements (like } \\
\text { vitamins or minerals) }\end{array}$} & Yes & $\begin{array}{l}\text { The service recommends supplements if a lack is } \\
\text { detected }\end{array}$ \\
\hline & No & No supplements \\
\hline \multirow{4}{*}{ Price (monthly amount) } & $10 €$ & $10 € /$ month \\
\hline & $20 €$ & $20 € /$ month \\
\hline & $30 €$ & $30 € /$ month \\
\hline & $40 €$ & $40 € /$ month \\
\hline
\end{tabular}

With the attributes and levels selection in Table 10 we created a new $4^{2} \times 2^{4}$ design and conducted another online survey on a $\mathrm{N}=52$ sample of the Spanish population (populationrepresentative respondent panel). Analysing the results, we notice that respondents showed a notable lack of engagement with the DCE task for several reasons: 1) the lack of significance in the statistical analysis of the preferences, 2) the short time the respondents spent responding to the questionnaire (mean of 9.13 minutes vs. minimum 15 minutes we estimated it would take to read the instructions and answer the questions), and 3) $48 \%$ of respondents failed the validation question (an additional choice set with a dominant alternative). To solve it, we introduced the changes mentioned in the main text.

\section{Warm-up question}

The training question had a dominant option (option A) revealed to the respondent if they selected option $\mathrm{B}$. The respondents were warned that the following questions will not have a dominant 
option. (Icons made by "Freepik", "turkkub", "Smashicons" and "Good Ware" from www.flaticon.com).

Fig. 3. Warm-up question

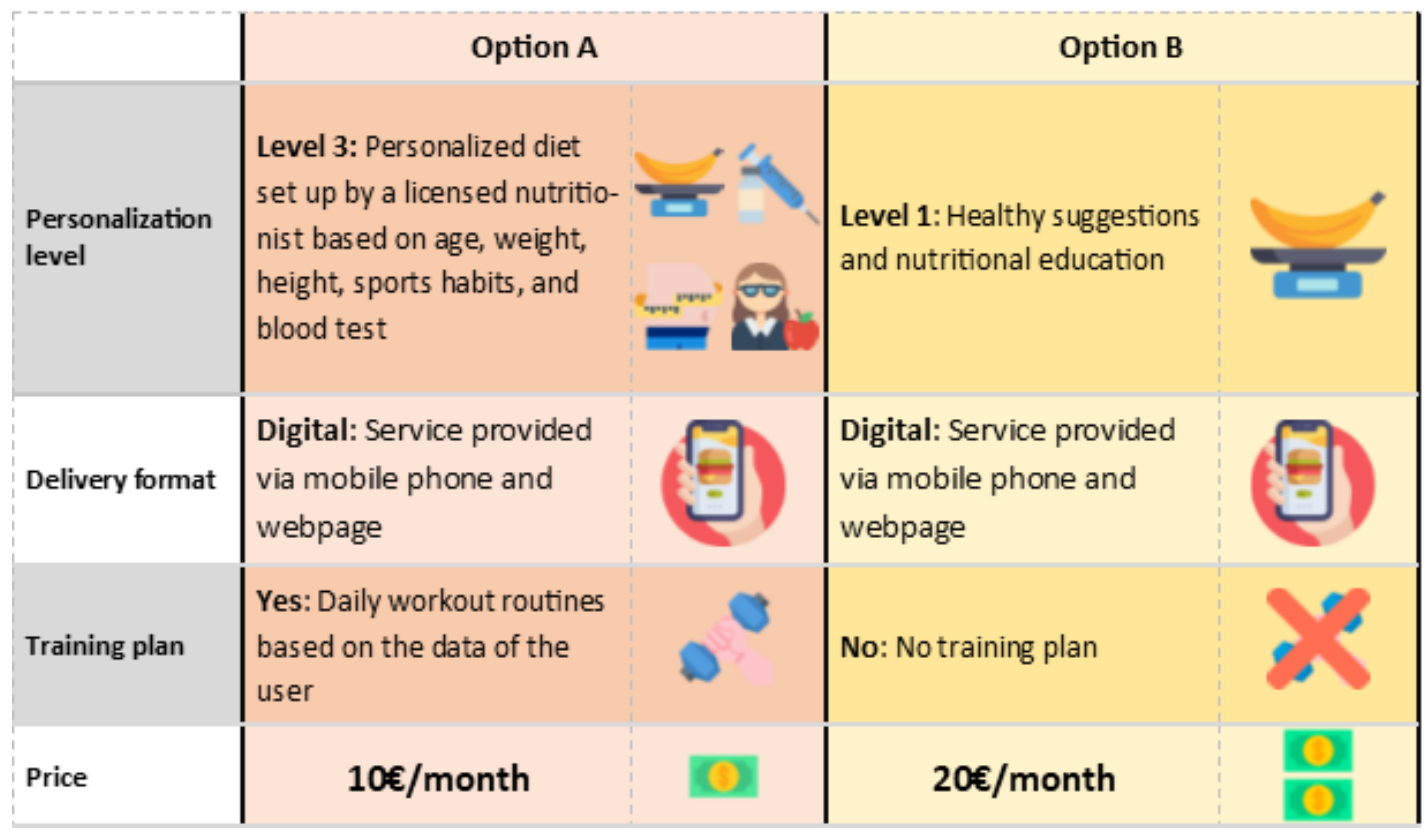

\section{Introductory text}

INTRODUCTION: Dear respondent, you are about to answer a questionnaire that will contribute to academic research on personalised nutrition. Your data will not be used for commercial purposes, and your answers are completely anonymous. Please answer truthfully, otherwise these results will be useless.

INSTRUCTIONS: Introductory text: A balanced diet adapted to our body is necessary to reduce the chances of developing a chronic disease. Recently, it has been discovered that, as well as other characteristics, the intestinal microbiota (the group of bacteria that inhabit the human intestine) functions as a mediator between the food we eat and our metabolism. Thus, a personalised diet based on user's characteristics (such as gut microbiota) is very beneficial in improving health and making nutritional intake much healthier, and the more our diet is based on our body's parameters, the healthier it will be. How to respond to this survey: You will be presented with 9 scenarios in which there will be an option A and an option B. Each option is a different personalised nutrition service (with different characteristics). In each scenario, you will decide between $A$ and $B$.

Each of these options A and B has 4 different characteristics: 1) Personalisation level: there are 4 levels and the higher the level, the more personalised the diet. 2) Delivery format: the service can be provided in a physical location or through digital media (mobile application and website). 3) Sports routines: the service can contain sports routines adapted to your needs or not. 4) Price: the service can cost 10, 20, 30, or 40 euros per month. 
Section C. Models details

\section{Conditional Logit Model}

Since we are coding each attribute level as a dummy variable and constraining one of the levels to zero (as the base level), the coefficients can be interpreted as the marginal utility over the constrained level. Following the probability function of the logit model, the probability that an individual $n$ choose the alternative $i$ is given by $\operatorname{Pr}\left(y_{n i}=1\right)=\frac{\exp \left(X_{i} \beta\right)}{\Sigma_{j=1}^{J} \exp \left(X_{j} \beta\right)}$. and the likelihood function can be expressed as $L=\prod_{n=1}^{N} \prod_{j=1}^{J} \operatorname{Pr}\left(y_{n i}=1\right)^{d_{n j}}$ (where $d_{n i}$ is 1 if $i=j$ and 0 otherwise). We computed this model using the command -clogit- in STATA and specifying the option 'vce (cluster $i$ )' which relaxes the assumption of independence in the answers of the same respondent (because in our data we have eight observations per respondent).

\section{Mixed Mogit Model / Random Parameters Logit Model}

In the XLM, the probability of election of one alternative over the rest is given by $\operatorname{Pr}\left(y_{n i}=1\right)=$ $\int\left(\frac{\exp \left(\beta X_{n i}\right)}{\sum_{j=1}^{J} \llbracket \exp \left(\beta X_{n j} \rrbracket\right)}\right) f(\beta) d \beta$, where $f(\beta)$ is a density function that we have to specify. In our case, we specified a normal distribution using the command -mixlogit-25 in Stata, which performs a simulation once the distribution is known. The probability is given, then, by the following

expression: $\operatorname{Pr}\left(y_{n i}=1\right)=\int\left(\frac{\exp \left(\beta X_{n i}\right)}{\sum_{j=1}^{J} \exp \left(\beta X_{n j}\right)}\right) f(\beta \mid \mu, \sigma) d \beta$. The simulation consisted of obtaining $\beta$ from random values of $\mu$ and $\sigma$, and repeating this process $R$ times, getting $\beta^{1}, \beta^{2} \ldots \beta^{R}$ values of beta that can be introduced in the logit formula and average those $R$ simulated probabilities. Then, we can introduce the simulated probabilities into the simulated log-likelihood function: $S L L=$ $\sum_{i=1}^{I} \sum_{j=1}^{J} d_{i j} \ln \widehat{P_{l J}}$.

\section{Price as a lineal variable}

We assumed that the price variable was linear with respect to the selection probability of the respondent. To test it, we followed the next approach:

- We estimated the conditional logit model specifying the price variables as categorical variables.

- We used the nlcom command in Stata to test the relationship between the coefficients of the price variable specified as categorical.

- We made two estimations:

- Difference between the $30 €$ coefficient and the $20 €$ coefficient.

- Difference between the $40 €$ coefficient and the $30 €$ coefficient.

- The difference between the $20 €$ coefficient and the $10 €$ coefficient was the $20 €$ coefficient.

- Given these figures, we only needed to test if they were different from eachother

Table 15. Analysis of the linearity of the price variable 


\begin{tabular}{|c|c|c|c|}
\hline Differences & $\beta_{20 €-10 €}$ & $\beta_{30 €-20 €}$ & $\beta_{40 €-30 €}$ \\
\hline$\beta_{20 €-10 €}$ & & $0.1277(\mathrm{p}-\mathrm{val} .:$ & 0.1008 (p-val.: \\
& & $0.174)$ & $0.216)$ \\
\hline$\beta_{30 €-20 €}$ & & & 0.0269 (p-val.: \\
& & & $0.731)$ \\
\hline$\beta_{40 €-30 €}$ & & & \\
\hline
\end{tabular}

Given that there are no significant differences in the "gap" between the categorical price coefficients, we keep our linearity assumption.

\section{D-efficient designs}

The module -dcreate- in Stata (developed by Arne R. Hole) uses a modification of the Fedorov algorithm, adapted by Zwerina et al. (20) from Kuhfeld et al (21) to meet the requirements in Huber and Zwerina (22): a) level balance, b) orthogonality, c) minimal level overlap, and d) utility balance. The Fedorov (modified) algorithm is a computer-based process that switches and compares attributes and levels simultaneously until it maximises the determinant of the inverse of the variance-covariance matrix resulting in greater accuracy of the $\beta$ estimators (20). Good design principles are approximated through this procedure but probably never reached because it is impossible for most combinations. This process, compared with the optimal designs (which only need to meet two requirements: orthogonality and level balance (23)), requires the "prior" coefficients of the future CLM to balance the utility among options in the same choice set. In other projects, the researchers generated the priors intuitively or set them to zero, but in our case, we based them on the pilot experiments' results.

Section D. Sample details

We estimated the personal income from each income range as being the upper and the lowest values in the range, and the total number of members in the house. The same comparison was made with the education ranges. The poor representation of the income of people with only primary education is due to the low number of respondents with primary education (only 3 ).

Table 16. Age and personal income: INE vs sample

Table 17. Education and personal income. INE vs sample

\begin{tabular}{|c|c|c|c|c|c|}
\hline Age & INE & Sample & Education level & INE & Sample \\
\hline $16-29$ & $10,156.00 €$ & $9,855.89 €$ & Primary education & $9,466.00 €$ & $3,404.01 €$ \\
\hline $30-44$ & $11,397.00 €$ & $11,994.34 €$ & Secondary education (I) & $9,534.00 €$ & $8,298.53 €$ \\
\hline $45-64$ & $12,550.00 €$ & $12,598.70 €$ & Secondary education (II) & $11,344.00 €$ & $10,937.40 €$ \\
\hline 65 & $12,758.00 €$ & $13,339.38 €$ & Superior education & $16,103.00 €$ & $14,480.39 €$ \\
\hline
\end{tabular}


Regarding the educational level, we can confirm that our sample contains less low-educated people and more high-educated people than the national average.

Table 18. Education level in the sample vs. national level

\begin{tabular}{lcc}
\hline Education & $\begin{array}{c}\text { Sample } \\
(\%)\end{array}$ & $\begin{array}{c}\text { INE (national } \\
\text { statistics) } \\
(\%)\end{array}$ \\
\hline No education & 0 & \\
Primary education & 0.65 & 38.7 \\
Secondary education & 8.44 & \\
\hline Pre university education & 18.18 & \\
Vocational formation I & 12.99 & 22.75 \\
Vocational formation II & 12.77 & \\
\hline University degree & 35.5 & \multirow{2}{*}{38.55} \\
Postgraduate & 11.47 & \\
\hline
\end{tabular}




\section{References for supplementary material}

1. Ballco P, De Magistris T. Spanish consumer purchase behaviour and stated preferences for yoghurts with nutritional and health claims. Nutrients [Internet]. 2019 Nov 1 [cited 2021 Feb 1];11(11). Available from: https://pubmed.ncbi.nlm.nih.gov/31726708/

2. Veldwijk J, Lambooij MS, Van Gils PF, Struijs JN, Smit HA, De Wit GA. Type 2 diabetes patients' preferences and willingness to pay for lifestyle programs: A discrete choice experiment. BMC Public Health [Internet]. 2013 Nov 29 [cited 2021 Feb 1];13(1):1099. Available from: http://bmcpublichealth.biomedcentral.com/articles/10.1186/1471-245813-1099

3. Rankin A, Bunting BP, Poínhos R, Van Der Lans IA, Fischer ARH, Kuznesof S, et al. Food choice motives, attitude towards and intention to adopt personalised nutrition. Public Health Nutr [Internet]. 2018 Oct 1 [cited 2021 Feb 1];21(14):2606-16. Available from: https://www.cambridge.org/core.

4. Molema C, Veldwijk J, Wendel-Vos W, De Wit A, van de Goor I, Schuit J. Chronically ill patients' preferences for a financial incentive in a lifestyle intervention. Results of a discrete choice experiment. PLoS One [Internet]. 2019 Jul 1 [cited 2021 Feb 1];14(7). Available from: https://pubmed.ncbi.nlm.nih.gov/31344135/

5. Determann D, Lambooij MS, Gyrd-Hansen D, de Bekker-Grob EW, Steyerberg EW, Heldoorn M, et al. Personal health records in the Netherlands: Potential user preferences quantified by a discrete choice experiment. J Am Med Informatics Assoc [Internet]. 2017 [cited $2021 \mathrm{Feb}$ 1];24(3):529-36. Available from: https://pubmed.ncbi.nlm.nih.gov/28011592/

6. Foltz JL, Harris DM, Blanck HM. Support among U.S. adults for local and state policies to increase fruit and vegetable access. Am J Prev Med [Internet]. 2012 Sep [cited 2021 Feb 1];43(3 SUPPL.2). Available from: https://pubmed.ncbi.nlm.nih.gov/22898158/

7. Haugen HA, Tran Z V., Wyatt HR, Barry MJ, Hill JO. Using Telehealth to Increase Participation in Weight Maintenance Programs**. Obesity [Internet]. 2007 Dec 1 [cited 2021 Feb 1];15(12):3067-77. Available from: http://doi.wiley.com/10.1038/oby.2007.365

8. Smith KJ, Kuo S, Zgibor JC, McTigue KM, Hess R, Bhargava T, et al. Cost effectiveness of an internet-delivered lifestyle intervention in primary care patients with high cardiovascular risk. Prev Med (Baltim). 2016 Jun 1;87:103-9.

9. Han MK, Cho B, Kwon H, Son KY, Lee H, Lee JK, et al. A mobile-based comprehensive weight reduction program for the workplace (health-on): Development and pilot study. JMIR mHealth uHealth. 2019;7(11).

10. Vallée Marcotte B, Cormier H, Garneau V, Robitaille J, Desroches S, Vohl M-C. Nutrigenetic Testing for Personalized Nutrition: An Evaluation of Public Perceptions, Attitudes, and Concerns in a Population of French Canadians. Lifestyle Genomics [Internet]. 2018 Aug 1 [cited 2021 Feb 1];11(3-6):155-62. Available from: https://www.karger.com/Article/FullText/499626

11. Feng-Gu E, Everett J, Brown RCH, Maslen H, Oakley J, Savulescu J. Prospective Intention-Based Lifestyle Contracts: mHealth Technology and Responsibility in Healthcare. Heal Care Anal [Internet]. 2021 Jan 11 [cited 2021 Feb 1];1-24. Available from: https://doi.org/10.1007/s10728-020-00424-8

12. Poínhos R, van der Lans IA, Rankin A, Fischer ARH, Bunting B, Kuznesof S, et al. Psychological Determinants of Consumer Acceptance of Personalised Nutrition in 9 European Countries. Lucidi F, editor. PLoS One [Internet]. 2014 Oct 21 [cited 2021 Feb 1];9(10):e110614. Available from: https://dx.plos.org/10.1371/journal.pone.0110614 
13. Stewart-Knox B, Rankin A, Kuznesof S, Poínhos R, Vaz De Almeida MD, Fischer A, et al. Promoting healthy dietary behaviour through personalised nutrition: Technology push or technology pull? In: Proceedings of the Nutrition Society [Internet]. Cambridge University Press; 2015 [cited 2021 Feb 1]. p. 171-6. Available from:

https://doi.org/10.1017/S0029665114001529

14. Rankin A, Kuznesof S, Frewer LJ, Orr K, Davison J, De Almeida MDV, et al. Public perceptions of personalised nutrition through the lens of Social Cognitive Theory. J Health Psychol [Internet]. 2017 Sep 1 [cited 2021 Feb 1];22(10):1233-42. Available from: http://journals.sagepub.com/doi/10.1177/1359105315624750

15. Fischer ARH, Berezowska A, Van Der Lans IA, Ronteltap A, Rankin A, Kuznesof S, et al. Willingness to pay for personalised nutrition across Europe. Eur J Public Health. 2016;26(4):640-4.

16. Mustapa MAC, Amin L, Frewer LJ. Predictors of stakeholders' intention to adopt nutrigenomics. Genes Nutr [Internet]. 2020 Sep 22 [cited 2021 Feb 1];15(1):1-15. Available from: https://doi.org/10.1186/s12263-020-00676-y

17. Mattei J, Alfonso C. Strategies for Healthy Eating Promotion and Behavioral Change Perceived as Effective by Nutrition Professionals: A Mixed-Methods Study. Front Nutr [Internet]. 2020 Aug 14 [cited 2021 Feb 1];7:114. Available from: https://www.frontiersin.org/article/10.3389/fnut.2020.00114/full

18. Chang J, Savage SJ, Waldman DM. Estimating Willingness to Pay for Online Health Services with Discrete-Choice Experiments. Appl Health Econ Health Policy [Internet]. 2017 Aug 1 [cited $2021 \mathrm{Feb} 1$ ]; 15(4):491-500. Available from: http://sites.google.com/site/jieunc1978/

19. Street DJ, Burgess L, Louviere JJ. Quick and easy choice sets: Constructing optimal and nearly optimal stated choice experiments. Int J Res Mark [Internet]. 2005 Dec 1 [cited 2019 Nov 11];22(4):459-70. Available from:

https://www.sciencedirect.com/science/article/pii/S0167811605000510 